\title{
"It's no longer the same job": robotization among breeders and dairy cows
}

\author{
Jeremy Deturche' \\ ' Universidade Federal de Santa Catarina, Florianópolis/SC, Brasil
}

\begin{abstract}
In agriculture, mechanization and robotization are two terms that are generally associated with processes characteristic of a "Green Revolution": industrialization, cost reduction and "rationalization", increased output and modernization. In this article, I reflect on the relations implied in this evolutionary-style narrative through an ethnography of cattle breeders and dairy cows in Haute-Savoie, France. I will show that the technical transformation engendered by the implementation of a milking robot is, first and foremost, a reconfiguration of the relationships between humans and cows. I will analyse the effects of the milking robot for both humans and cows through the notion of 'technical objects' and their associated environment, which configure a transformation in the technical system linked to the process of domestication. I show that modifications in the rhythm, gestures and interactions with the animals also redefine how cows are made to produce milk, and that, furthermore, this does not necessarily constitute a virtualization, an objectification or distancing in relation to the animals. In brief, it lacks many of the defining features of 'industrialization'.
\end{abstract}

Key words: domestication; robotic milking system; technical mediation; agricultural systems. 


\section{"Não é mais o mesmo trabalho": a robotização entre criadores e vacas leiteiras}

\section{Resumo}

Na agricultura, mecanização e robotização são dois termos geralmente associados a processos usados para caracterizar a "revolução verde"; industrialização, redução dos custos e "racionalização", aumento da produção e modernização. Neste artigo, proponho uma reflexão, a partir de uma etnografia realizada junto a criadores de vacas leiteiras na França (Haute-Savoie), sobre as relações apontadas nessa narrativa de cunho evolucionista. A partir da transformação técnica constituida pela implantação de um robô de ordenha, tentarei mostrar que se trata, antes de tudo, de uma reconfiguração relacional entre homem/ vacas. Analisarei as praticas que são implicadas pelo robô de ordenha, tanto para os homens quanto as vacas, a partir de noção de objetos técnicos e meio associado. Configurando assim uma transformação do sistema técnico ligado ao processo de domesticação. Meu objetivo é demonstrar que, a partir de modificações nos ritmos, nos gestos e na interação com os animais, existe uma redefinição da maneira de fazer as vacas produzirem leite, e que isso não configura necessariamente uma virtualização, uma objetificação ou um distanciamento em relação aos animais, ou seja, uma industrialização.

Palavras-chave: domesticação; robôs de ordenha; mediação técnica; sistemas agrícolas. 


\title{
"It's no longer the same job": robotization among breeders and dairy cows
}

\author{
Jeremy Deturche
}

\section{“Post-productivist" agricultures and the Green Revolution'}

The productivist drive in agriculture that dominated the "Green Revolution" (with its focus on quantity) had, as its main pillars, an increase in mechanization, the widespread use of various "phytosanitary products", cost reductions, and stimuli towards industrialization. This verticalized movement framed farmers as the recipients of practices that had been projected and masterminded elsewhere, derived from national policies of food management, laboratories, big firms, and engineering and zoo-technical schools (Mazoyer \& Roudart 2009).

Since the 1980 , this movement has faced a number of increasingly acute crises in what pertains to the environmental, social or even productive spheres. We are effectively witnessing a number of initiatives that seek to reconsider the agricultural model "from the top". ${ }^{2}$ These policies affect the practices of farmers, promoting the diversification of productive techniques, and a reconfiguration of their self-image. We thus encounter constant conflicts over what it means to be an "agricultural producer", with representations that derive from the Capitalist industrial model (CEO, agricultural entrepreneur, agricultural manager, rural producer, or definitions linked to the agribusiness model) and more complex identity claims that salvage, or seek to salvage, a specific way of being (farmer, breeder, peasant, tiller, paysans) associated with sustainable practices. Notice, however, that definitions are ambiguous, and that techniques and identity claims can be interwoven in complex ways. Thus, for example, organic production can be linked to identity practices of small-scale farming, while also being a large-scale industrialized mode of production.

We can distinguish varieties of strategies and diversification, depending on what the farmer focuses on. In the European ethnography that I will present in this article, it must be considered that the diversification of modes of production occurs within the context of a politically-structured continental policy that resulted in the unsustainability of the productivist model, forcing farmers to adapt. The unsustainability of the model results not so much from radical changes in the paradigm of agricultural policies, but above all from the endless socioeconomic crisis that has been punishing agriculturalists in general, and in specific those working with dairy (Droz 2002; Droz et al. 2014; Droz \& Forney 2007).

Faced with this situation, the response of farmers has, in part, retained a local character: their choice of competing agricultural systems have become diversified and varied. Some authors propose to interpret this diversity through a so-called post-positivist paradigm, wherein agricultural aims and objectives cannot be reduced to "rationalization" and to an increase in production, but rather convey various types of practices and objectives in a systematic and sustainable way (Dubois \& Sauvée, 2016). From a socioeconomic point of view, Forney (2012), studying the Swiss case, distinguishes three main axes of, or paths, toward reorganization:

\footnotetext{
I would like to thank the members of the LACT - UNB, CANOA-UFSC and Anthropology Department of the Federal University of Santa Catarina for the discussion about this research and the IBP - Instituto Brasil Plural - UFSC for the material found that made it possible.

2 One of the characteristics of the Green Revolution is the separation of farmers - who are deemed to be mere executors of techniques and modalities of production - from the public and private spheres that develop agricultural policies (public institutes, ministries, large private laboratories, and ergonomic companies). The latter compose what is known as the "top", referring to their ascendency in the decision-making processes which determine the knowledge that will be "applied" by farmers, the latter thereby demoted to the category of "producers" (Bedoussac \& al. 2013; Bonneuil \& Demeulenaere 2007).
} 
1. Specialization in excellence and quality, which globally continues to conform to what he calls an "industrial" orientation, an idea that will be called into question below.

2. The organic option / PDO (Protected Designation of Origin), which constitute specific niches.

3. The diversification of produce and services, such as the "paid landscaping services", for instance3. This strategy may develop into modes of permaculture or agroforestry.

These options, it must be stressed, represent paths that do not allow for purely local choices. Even when they take into account the opinions and orientations of farmers, they only do so through State policies, so that the participation of public powers emerges as a mediator of the relation with "consumers" or companies in the private sector. PDOs are exemplary in this sense, since they necessarily result from a negotiation involving farmers, producers, and public agencies that sanction and provide legal and economic assurances, thus resembling process of heritage listing (Micoud 2004; Lizet 1998; Ricard 1998).

Figure 1 - Cow waiting to be milked in a mechanized system.

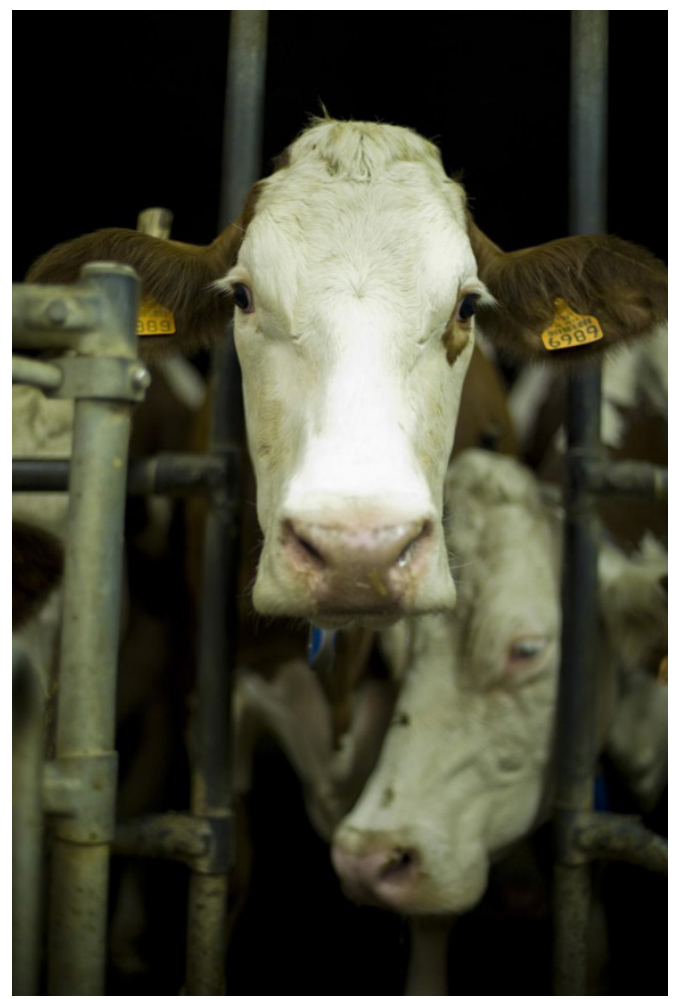

Photo alexmouthon@

These paths, however, are not mutually exclusive, as revealed by the research I have been carrying out since 2001 among dairy cow breeders in France (near the Swiss border). Here, while the general economic orientation conforms to Forney's first axis, which takes place within a PDO context, it does not exclude diversification through polyculture and steadfast identity claims (Deturche, 2012).

\footnotetext{
3 Swiss agricultural policy includes subsidies for practices that upkeep a certain landscape, in the context of care for mountain landscapes. These include, for instance, subsidies for cutting hay after a predetermined date, to allow field plants to produce seeds, thus maintaining a variety of flower species in mountainous areas.
} 


\section{Robotization, mechanization and technical transformation}

Mechanization or robotization are two terms that, at first, appear tied to processes linked to the Green Revolution. In what pertains to dairy production, we would be dealing with the quasi-“Fordization" of work with animals and, thus, with an increasing objectification of cows, which would conform to the Forney's first axis and would be the final avatar of industrialization. This "reaction in continuity" to the problems of agriculture throughout the world plays an important role in processes that seek more precise answers, guided and controlled by more rigorous parameters, defined by a significant rise in the use of technological resources. We are here faced with so-called precision agriculture (Lebrun 2016) and with the "technophile" demands of the sector (Franzoni 2017; Roscoe 2013) ${ }^{4}$ - a phenomenon present in many different narratives of agriculture, mainly in agribusiness and more industrialized sectors involved in the modernization of agricultural production. This positivist narrative is particularly developed in the discourse of consultancy agencies that provide aid to farmers. It is through it, for example, that the "genomic revolution" in bovine selection was presented (Deturche 2017), or that precision agriculture is depicted in the many sites that offer aid and advice to Brazilian agribusiness.

Many people say that Brazil has not progressed much in the area of science, technology and innovation. It is true that progress is slight in many of the sectors of the economy. We lack the culture of investing in industrial research. Companies innovate little and we lose competitiveness before our competitors. But is it fair to say that this is also true of the Brazilian economic locomotive? Does farming also innovate little in Brazil?

The Brazil of the "naïve hick" is gradually a thing of nostalgic minds. The numbers of the farming industry constantly invade the news (Roscoe, 2013: 1).

With data obtained from technology, the farmer can manage the field of production in a precise manner, and obtain a much more positive result from his activities. The more efficiency he has in the application of the available resources, the more chance he has of ensuring the quality of his activity. Thus, technology, and more specifically precision agriculture, have contributed to the profitability and the growing development of agribusiness in the countrys.

These two passages, written by the Brazilian agribusiness sector, reveal how this positivist narrative is constructed, with technology emerging as the main factor in progress, leaving behind the "naïve hick" and taking agriculture into the modern world, symbolized by ever-growing production numbers.

In this article, I reflect on the relations that this narrative trace between industrialization, use of technological resources, mechanization, and robotization, in the dairy sector.

My research was carried out among specialists in cattle breeding, particularly of the Montbéliarde breed, which are considered to be of high genetic quality, and which follow a particular "performance" pattern. Dairy is an important element in this context, but it is not the only one: among the breeders I researched, "investment" in cows went beyond the mere production of milk, carrying with it, as well, a heavy symbolic and affective load. This investment was accompanied by a generally favourable view of the modification of technical apparatus and an openness to "new technologies". Breeders are thus involved with new techniques of reproduction and selection, which require genetic analyses, embryo transfers, and assisted reproduction (Deturche 2012, 2017; see Leal 2016 for the elite cattle breeding in Brazil).

\footnotetext{
See, for instance, agribusiness blogs in Brazil, such as InCeres or RuralCentro.

News from the website santanderempresasenegocios, from August 2017. Consulted in May 2018.
} 
Since the last decade, an important technical procedure has been developing. Although introduced in the 1990s, it was only effectively appropriated by breeders towards the end of the 200os, when it was, finally, considered to be "ready". This procedure has a direct impact on what many breeders see as the "heart of their profession": milking. The most visible aspect of this new technology is a robot that "automatically" carried out this task. Milking dairy cows, which exist mainly to produce milk ${ }^{6}$, is the pinnacle or paradigm of working with them, and it can metonymically express the totality of the farming work involved. It is representative of the ethos of "caring for the animals" (soigner les animaux) and of the profession more broadly: it is the métier of the breeders.

What meanings are implicated in different ways of milking, and particularly in the passage from a so-called mechanic, or semi-automatic, technique, to a robotized system? How does this transform affect forms of representation, ways of making, raising, and the gestures and rhythms associated with milking? What engagements and jumble of relations become reconfigured by robotized milking? How does robotization/ mechanization interfere in relations between breeders and cows? Or in how breeders see and understand their animals, and how the latter react to this technical mediation?

Ethnographically, these questions mesh with what farmers have to say about the installation of a milking robot, and what it implies for their practices and relations with cows. What type of milking is "milking with a mouse" (Forney 2012: 10)? What is implied in the "loss of the herd/drove effect" noticed by the breeders? Finally, how do they perceive the differences thereby implied when they say that, ever since the robot was installed, "it's no longer the same job"?

In answering these questions we are also called to reflect on what the robot means in terms of industrialization and conservation, maintenance and the strengthening of a process of Cartesian objectification of cows. Instead of taking the robot to be a technological resource that causes a process of industrialization, like the modernization of pig husbandry which transformed pigs into a "product" (Porcher 2002; Mouret 2012), for example, we should be open to the uses, configurations and relations that the robot establishes in the technical process of domesticating cows (the "domestication system"). Domestication should here be taken in a wide sense, one which, precisely, is not limited to a relation of domination, and does not characterize the state of certain animals. We should integrate current thinking on domestication, which does not consider it to be a singular and linear acting on the natural world, as synthesized by Lein (2018) for eider ducks in Vega Island, Norway. The author prefers to speak of assemblage, or to adopt Fijn's definition of 'codomestic relationship': "the social adaptation of animals in association with human beings by the means of mutual cross-species interaction and social engagement" (Fijn 2011, 220, emphasis in original)" (p. 129).

As Tsing (2018) and others observe, the problem with definitions of this type is that they are so broad that they are unable to explain what exactly domestication is. I cannot resume this discussion here; what interests me is the possibility of identifying a non-unidirectional relation, which allows (indeed, requires) us to be attentive to the complexity and reciprocity of human-animal relations, even in contexts in which a more restrictive or classic definition of 'domestication' would apply. The cows my research is concerned with are, in effect, a paradigmatic example of the definition of domestication. As Ferret notes in an article with the provocative title of Outils vivant? De la manipulation des animaux (2016; 'Living tools? On the manipulation of animals'), attention to complexity should not blind us of the asymmetry involved in these relations.

\footnotetext{
6 Today most dairy cows are specialized breeds.

"Traire à la souris" (my translation). Unless otherwise stated, all translations from French are my own.

Cf. Digard (1988; 1990), who coined the expression système domesticatoire to remove relations of domestication from the scope of relations of economic production, conferring on them the dimension of a total social fact. This expression is clearly related to the idea of a technical system, developed by the anthropology of technique from the works of Gille (see Lemonnier 1986, 1992, 2010; Coupaye 2009, 2015).
} 
My perspective in this article incorporates a clear recognition of the relational asymmetries implied in breeding dairy cows (what Ferret calls "anthropocentrism" (ibid.)). However, this allows us to apprehend the construction of the subjectivities at stake with greater nuance.

Thus, combining the possibilities contained in the idea of "technical system", we can think of the critiques of domestication, coming both from the anthropology of technique (Sigaut, 1988; Haudricourt et Dibie, 1988) and from post-humanism, in terms of techniques (as social relations) and daily practices in relation to animals. I believe that it is possible to thereby identify complex characteristics of the relation between humans and animals as mediated by techniques and technical objects - such as robots.

I will focus specifically on the practices that are implied by the robot for breeders (and for cows, as we shall see) in their relations with animals. Using a robot transforms human-cow relations, but also cow-machine/ robot, and human-robot/machine relations.

In The Percpetion of the Environment, Ingold (2000a) discusses the impacts of mechanization and industrialization from the point of view of animals, focusing on domestication through the notion of 'skill'. This latter concept is defined by five main points:

Pour definir plus précisement ce que j'entend para habilité je souligne cinq dimensions discriminantes de toute pratique habile. Premièrement, viennent l'intentionnalité et la fonctionnalité qui plutôt que d'être des propriétés préexistantes d'un agent ou d'un instrument sont intimement liées à la pratique proprement dite. Deuxièmement, l'habilité n'est pas un attribut du corps isolé d'un individu, mais partie integrante d'un système de relations matérialisé par la présence de l'artisan dans son environnement. Troisièmement, plutôt que d'être l'expression d'une simple application d'une force mécanique, l'habilité implique des qualités de soin, de jugement et de dextérité. Quatrièmement, ce n'est pas à travers la transmission de formules que les habilités passent d'une génération à une autre mais par la pratique et l'expérience, "les mains dedans". Finalement, le savoir-faire n'est pas la pour réaliser un dessein préexistant mais plus précisément pour générer les formes des artefacts. (2010: 290, print version).

Through this definition, Ingold reflects on processes of industrialization and mechanization that are characteristic of the West. However, he also notes a certain ambiguity related to the difficulty of distinguishing mechanization or robotization from processes of industrialization and development of the Capitalist system. Although they are undeniably historically linked, we must encounter a non-naturalized way of conceiving of this relation. This leads him to a critique of the notion of technology:

Instead of assuming that technical operations are, by their very nature, mechanical, I argue in this chapter that the machine is an outcome of the historical development of the forces of production accompanying the growth of industrial capitalism. In this development the relations between workers, tools and raw material have been transformed, such as to replace subject-centred skills with objective principles of mechanical functioning. It is to these principles that the modern concept of technology refers. I show how the emergence of this concept was bound up with the rise of a mechanistic cosmology that separated design from construction, and reduced skilled making to 'merely technical' execution. [...] I began to think that this picture of a progressive evolution from skill to technology, in which the craftsman or artisan gradually gives way to the machine operative, is too simple (2000a: 289-290).

This critique of "technology" in favour of the notion of "technique" is important, and recurs in other studies, particularly in the tradition of the anthropology of technique. I will highlight two justifications for this critique. First, the concept of technology is value-laden in a way that technique is not. In general, technology is conceived as the culmination of a process of evolution that is marked by a rupture between techniques (understood as ways of doing that are anterior to the development of science and of the industrial world - and which are, therefore, "primitive") and technology, which is both the product of and the means for the contemporary 
industrial and scientific age. The distinction between the "naïve hick" and the modern farmer in the citation above clearly captures this discursive distinction - along with an ethnocentric dichotomy (separating an intuitive technique from a technology that requires the application of prior scientific knowledge), this view, Sigaut (1985) reminds us, creates a competition among researchers seeking to establish when we crossed the Rubicon from technique to technology (see also Coupaye 2009; Coupaye \& Douny 2010).

The second reason is related to a point of view that is resolutely descriptive, regarding the potential that a concept such as 'technique' affords to an analytic descriptive methodology, thus reencountering the Maussian definition which founds the anthropology of technique (Mauss 2012a [1935], see also Sautchuk 2010). Use of the term "technique" does not appear to prejudge a transcendental difference between different ways of doing. In the case of domestication and farming processes, it prevents us from instating a radical divide between less mechanized and robotized techniques. I believe it is important to avoid a priori ruptures between ways of milking, and instead to analyse the social and relational implications of different ways of milking. We thus respect the social and technical logic that exist in the many forms of mediation between humans, animals, plants and medium.

By reconfiguring the use of machines through the notion of skill, Ingold seeks to escape the pitfalls of the notion of 'technology'. He shows that the implications in and transformations of the processes of mechanization do not necessarily correspond to an objectification, or a loss of skill, but rather to a transformation in the relations to objects.

Likewise the machine operative of industrial society remains a skilled practitioner: his skill, however, lies in coping with machines rather than in their operation, and what it produces is not commodities for the owner of capital but his own personal and social identity (2000a: 290).

However, Ingold's interpretation remains ambiguous, insofar as, throughout his oeuvre, we find a reaffirmation of the relation between mechanization, industrialization and the global loss or disappearance of skill. In the article Tools, mind and machines (Ingold 20oob), Ingold posits a correlation between skill and non-industrial processes. Later, returning to this issue, Ingold uses the notion of 'technical object' proposed by Simondon (2012 [1958]) to solve this ambiguity and to "save", once and for all, the notion of skill: through Simondon, the notion of skill can be reintegrated to processes of mechanization (Ingold 2011). This perspective furthermore leads the author to separate machines from automatons, as argued by Simondon, where the former characterizes open technical objects, and the latter defines self-closure within a programme.

These reflections will be my guide as I seek answers to the questions that I posed above, concerning the technical choices involved in implementation of a milking robot. Above all, they will allow me to consider this technical transformation in all of its implications and all of the uses it affords breeders in relation to their animals, and animals in relation to their breeders. 


\section{The Milking Robot}

The milking robot automatizes the milking of cows, which is otherwise carried out by hand or by methods of mechanized milking. The distinction between manual, mechanized and robotized milking is established by the breeders themselves, and by the advisors and technicians who participate in the implementation of this machinery. Briefly, milking by hand involves the extraction of milk by direct hand contact with the teats of a cow, in a rhythmic movement which causes milk to flow. Mechanized milking covers various methods, all of which involve a system of pumping milk through vacuum tubes. This system admits many possibilities, but in all of them humans intervene by fastening the teat cups (allowing for milking to take place in dedicated milking chambers (figure 2), rotating stations, or moveable posts). In mechanized milking, milk is placed directly in a cooling tank. Robotized milking delegates the work of fastening the teat cups to a robotic arm.

Figure 2: Mechanical milking installation with two rows ("docks") and cows in a "cob" formation. In the middle we see the pit were the breeders watch.

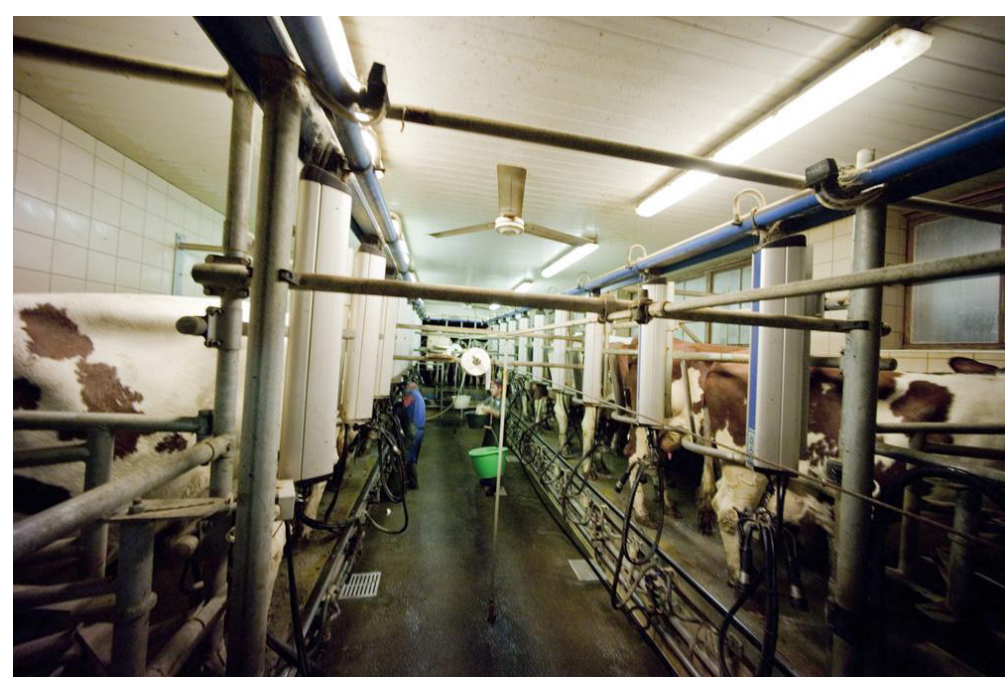

Photo alexmouthon@

Figure 3: Milking robot, cows beside it...

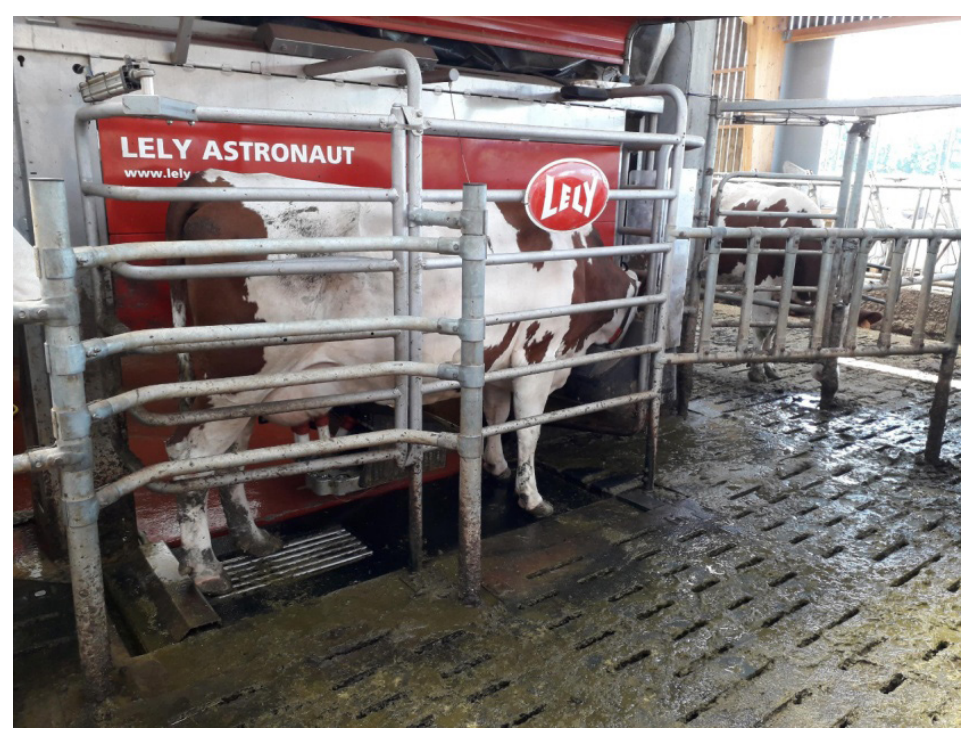

Photo by the Author. 
The decision to use a robot depends on a number of factors, which may be of an economic nature: improvement in production due to the individualization of the milking process; faster milking; free hands, and time for carrying out other tasks, instead of being constrained by an obligatory task that needs to be carried out daily, at set times'; more precise measurement of data, enabling a more accurate distribution of food supplements and attention to teat care. More time and economic gains are the benefits usually stressed by salesmen and technicians ${ }^{10}$, along with the trope of participating in the "modernization" of farming and in technophile positivism. Breeders, however, are aware that these are mainly sales pitches. Even if they are sensitive to these concerns, what influences the decision to adopt a robot is, first and foremost, an interest in gaining a deeper understanding of the animals (we will see shortly what this understanding consists of), and to improve the management of their herd. They thus do in fact seek to improve "production", but in terms of efficiency - apprehended according to criteria specific to breeders. The positivist argument is not enough. Furthermore, robotization requires high financial investment in a context in which there are no guarantees of financial returns. Thus an emphasis on financial gains is less significant for the breeders than the process that allows them to enhance their knowledge of the herd, learning to manage it with greater care, and individualizing relations with animals further. These are the gains that truly transform farming practices and the animal husbandry system.

Figure 4: Live, the quantity of milk by quarters, in kilograms.

On the left-hand column, there is a list of available items.

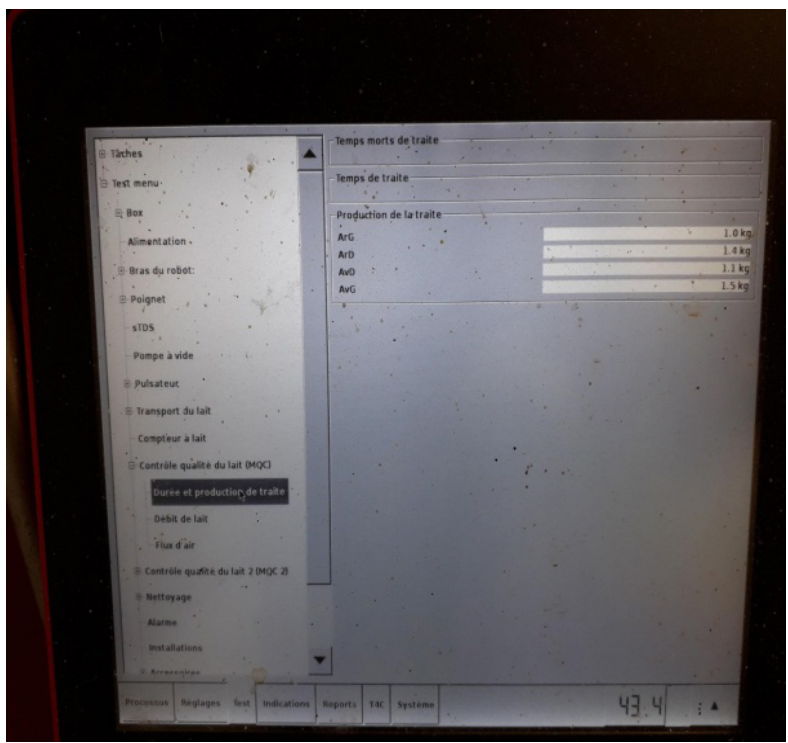

Photo by the author.

9 Lagneaux and Servais, for example, refer to an ad that claims to "free your hands to free your mind" (2014: 73), where we find a clear separation between technical and intellectual activities.

“Technicians" designates the different professions of advisor and salesmen (which are often combined). 
Figure 5: The robot's panel, human side. We see the name (Ladygaga), the weight, the amount of food supplements to which it is entitled, the total amount of milk obtained in this milking session (live), the time spent milking... This screen lies exactly on the other side of the robot. These data are furthermore available, as are other, in the computers connected to the robots.

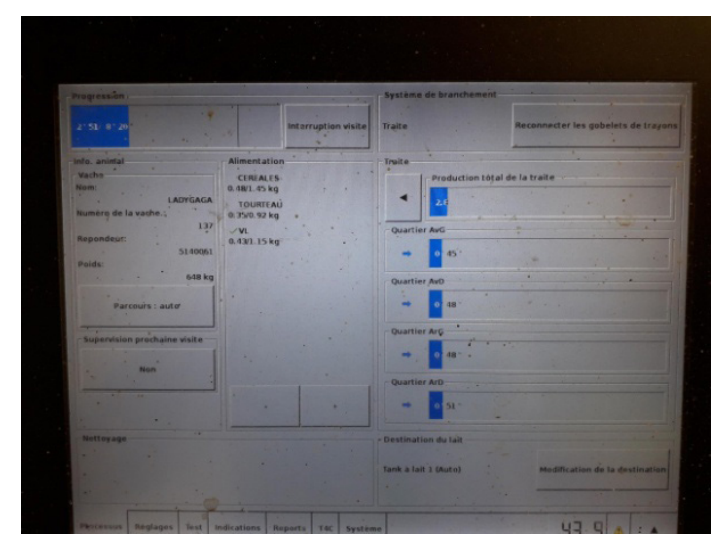

Photo by the author

In an article called De la traite robotisée au raid d'avatars. Incorporation et virtualisation, Lagneaux and Servais show how a virtual profile, not all that dissimilar to the avatars of videogames, is constituted via the robot. They show how the robot is able to transform the cow into data (2014: 88), making her available on a computer screen through controlling software. The screen displays global data on the herd, including median daily production, various graphs displaying different measures of productivity, and also state of health, as well as individual stats about each cow. These data are not limited to aspects of production relative to the quantity and quality of milk, but serve as indicators of the health of the animals - through the detection of possible teat infections or sudden slumps in productivity - as well as of their reproductive cycle (detecting moments of potential fertility) and so forth. By computing this information, relating it to the pedigree of the animal (ascendancy and descendance) and other indexes obtained through various animal management software, the robot produces a "virtual body" for the cow.

These data are not, in themselves, anything new. However, they are now systematized and, thus, easily and accurately retrievable. ${ }^{11}$ As a breeder told Lagneaux and Servais: "with the robot I am more within my animals" ${ }^{12}$. Efficiency, defined as an emic concept (Coupaye 2009, 2015), involves, first and foremost, an improved interaction, imbrication and entanglement with animals or assemblages (to recuperate Lien's (2018) term), even if this 'tangle' is controlled and defined by humans. ${ }^{13}$ In this assemblage, the robot is a mediator or facilitator. As I mentioned earlier, we are not, however, dealing with new data. While the robot may produce a "virtual cow" in the style of an avatar of modelled data, it is not the first such "virtual cow". Before the robot, and even now for those who do not have a robot, a large quantity of data available from various sources and types of analyses was already incorporated in the relation between breeders and animals ${ }^{14}$. The system of managing the breed is, in itself, a way of producing genealogies and qualitative analyses of the animals. Even without a robot, a cow already has a virtual portrait: the OS Montbéliard form ${ }^{15}$ (formerly the HerdBook for the breed)

\footnotetext{
11 The robot can provide, for instance, direct and real time data on milk production, weight, milking speed and quantity of milk per quart (photo).

12 "Avec le robot, je suis plus dans mes bêtes" (ibid: 74).

13 In this sense, Ferret (2016) provides us with an interesting provocation, recalling that even in the constitution of a "relational tissue without stitches" between animals and humans, we should not lose sight of the anthropocentrism and asymmetry of relations of domestication.

14 Elsewhere I have written of "paper cows" (Deturche 2017), but, as Prof. Rafael Devos reminded me, the term 'paper' is somewhat outdated.

15 OS means Organisme de selection, 'Selection Agency'.
} 
(Figure 6) or, more recently, the "genomic portrait" obtained through genetic analyses (see Deturche 2017). The system of milk control, carried out by external agencies, is also an important supplier of data, providing information on quantity and quality of production, and eventually raising health concerns. The difference is that these data are collected monthly and are generalized by algorithms so as to produce continuous graphs. In other words, for those already entangled in relations of domestication with cows, the robot is seen as a plus, a more complete and precise resource for compiling data used in the individualized management of the herd; that is, in feeding, reproducing and selecting the animals. The robot thus becomes a part of a system of breeding animals that is already constituted, rather than a revolutionary tool.

Figure 6: Example of a "paper cow". We find genealogical information, and notes on the different items that were chosen in the selection agencies.

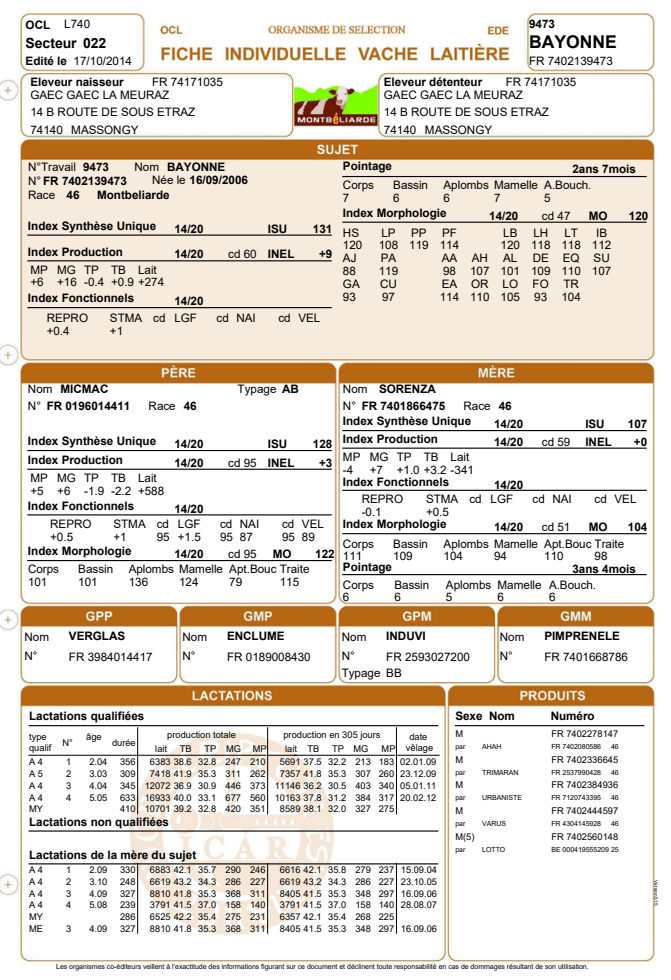

These virtual cows, constituted through the computation of data on animal bodies, are a constant in cattle rearing and they affect the choices made by breeders, participating in the various degrees of protected designation status (AOP, AOC, IGP' ${ }^{16}$ ) of local milk products (mainly cheese, but also butter and yogurt). However, these are not the cow-organisms with which the breeders deal on a corps-à-corps basis, to resume Lagneaux and Servais 'characterization. The virtual cows produced with resources such as the robot are engaged at the breeder's discretion for purposes of management and projection. Interacting with cow-organisms is a daily necessity, with a mutual aspect. The idea of "resonance" is a useful way of understanding the various interactions between breeders and the many syntheses of cows produced by gathered data. Breeders constantly make these data resonate with the cows that they live alongside, just as they compare these virtual bodies to one another: they consider genealogy and data concerning milk yields, behaviour of specific cows in the corrals, and so forth.

16 Appellation d'Origine Protégée (Protected Designations of Origin), Appellation d'Origine Contrôlée (Controlled Designation of Origin), Indication Géographie Protégée (Protected Geographical Indication). 
It is through this ability to make resonate many different cows that breeders are able to navigate the many dimensions of a complex agricultural system, embedded in an industrial and capitalist world. It is in this way that they can live and constitute themselves as cattle breeders: selling milk, cows, embryos, participating in local constructions of identity and managing the reproduction of their herd (Deturche 2012).

In what concerns the production of virtual cows, this reading helps us to understand how robots are inserted in the context of breeding in a system of domestication. However, it is not enough to clarify the associated nor how cows in a corral can, in fact, resonate with virtual cows. To understand this, we must pay closer attention to the practices of the robot, the way they are in fact used. Breeders are not constantly mesmerized by the data on their cows; the corps-à-corps is predominantly a relation of affect, of touching, of sensation, perception and coexistence.

The introduction of robot in a technical system does not only imply in the use of its "products", that is, the information that it gathers. In considering these questions, we should look to understand the synergy that is created in the corral between animals, men, space and robot, turning to how the introduction of a robot in a technical system occurs in daily practice.

Even this analysis would only provide us with a partial understanding of the motivations driving this technical choice. We cannot ignore, for example, the technophile appeal of the robot, which places its use into a broader dynamic. Simondon had already noted that, contrary to the expectations of common sense, including those represented in discourses on the "naïve hick", agriculturalists are not naturally refractory to technical innovation (1959, apud Guchet 2016: 140-141). Nonetheless, in a system in which most innovations and transformations come from public policies or top-down impositions, proposed changes are only rarely adequate to the existing agricultural system, and even more rarely do they take into account emic notions of efficacy.

The robots currently in use are presented as a feat of engineering. However, they result from coproduction (Darré 2001) with breeders, since the very first robots, introduced in the 199os, were considered inadequate for their intended results.

We still need to understand the breeders' view, presented at the start of this article: as producers of virtual cows, robots are in continuity with the former practices; however, the discourse of cattle breeders seem to point to a wider transformation, since, in their understanding, they are no longer part of the same profession (métier). We must thus investigate how this technical transformation transforms the system of domestication itself.

\section{Robots, technical objects and social mediation}

As part of their daily routine, robots effectively transform bodies into virtual avatars, converting them into numbers and indexes. This, however, results from the processing of data obtained during the period in which they function. For example: a health alert is flagged when abnormal conductivity is detected in milk, indicating the start of an infection in the udder. Breeders immediately receive the notification in their cell phones through an app that they must install, but the milk itself may be automatically discarded (if the robot is programmed to do so), thus avoiding the contamination of the tank where it is conserved until it is time to be collected.

In mechanized milking, the perception of a clinical problem in the udder of the cow is one of the abilities of the breeders. With robotization, we have more than a simple delegation, to the machines, of an ability that formerly fell to the breeders; indeed, what we find is a diversification and a transformation, since the way that the robot perceives the problem is not the same as how the breeder perceives it. Touch, visual perception, and observation of behavioural signs are not discarded with the analysis of the conductivity of milk by the robot. Even if humans no longer milk their cows twice a day, they continue to exercise their perceptive activities 
on other occasions. It is important to stress that breeders are adamant on the need to relate with their herds in a continuous manner - compensating the time that they would have spent together during breeding - by walking beside their animals. I will return to this point shortly.

Figure 7: The gesture of "connecting" the cow to a mechanical system. In this case, we see a milking installation behind the cow. Rotary system.

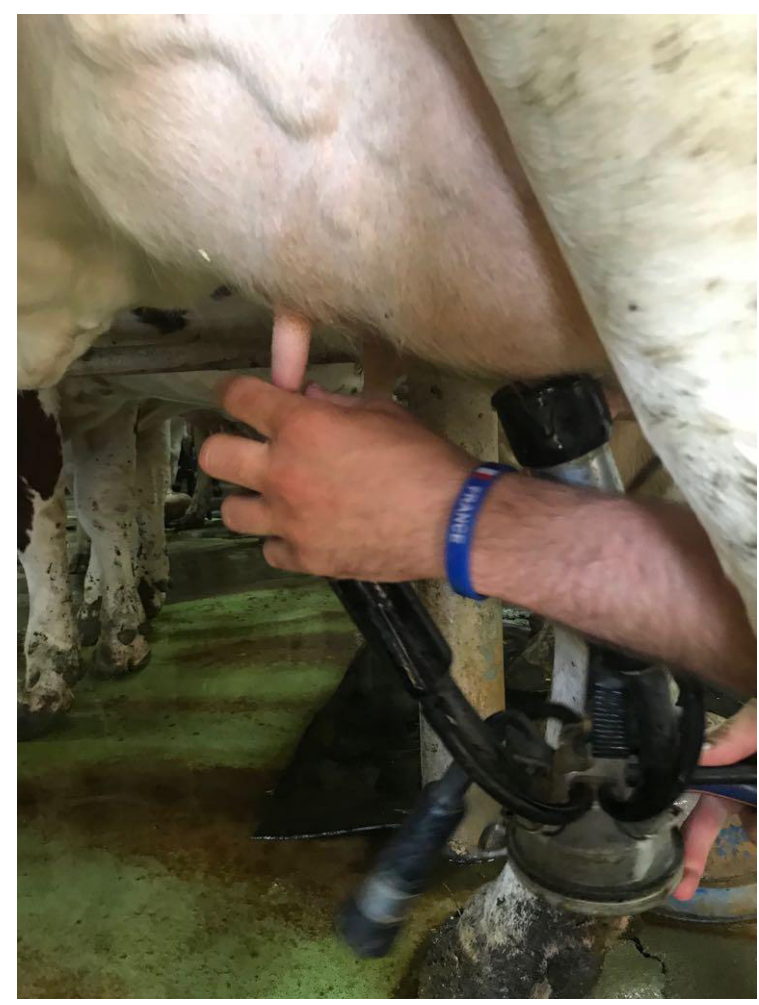

PhotoSamuelducloz@

I think that this is what is suggested by the breeder who told Lagneaux e Servais that he feels "more within his cows". This is not only because he has access to more precise and patterned data, producing virtual bodies (for instance, by separating the daily production of a cow into mammary quarters, rather than simply quantifying the production of the udder as a whole ${ }^{17}$ ), but also because he adds his abilities to the capacities of the robot.

The robot also has an adaptive capacity which is necessary for its proper functioning. Simondon attributes this capacity to adapt to the "margin of indetermination" of technical objects, which is necessary for their concretization (2012 [1958]: 11, 185-202). The robot can, for instance, adapt to modifications in the animals' udder during the lactation process and throughout their lives. In order to properly position the robotic $\operatorname{arm}^{18}$ that will extract milk, the robot must have the capacity to recognize the morphology of the udder and the position of the teats. The first time the cow enters the milking stall, the robot carries out a complete recognition through laser teat position sensors. This reading provides the basis for subsequent proceedings, when the robot will use the information obtained to speed up the process ${ }^{19}$.

\footnotetext{
17 A cow's udder is made up of four sets of mammary glands, designated "mammary quarters", or simply "quarters", which, depending on context, can be divided into anterior udder and posterior udder, each one with two quarters.

18 Which make direct contact with the teats of the cow (or other animals).

19 Cows are drawn to the milking unit by the offer of food supplements. The robot must control the quantities of these supplements made available to each cow - this is a decision of the breeders, which takes into account individualized criteria such as the daily milk production of each animal. The robot recognizes the cow by the chip it carries in a collar, which then allows it to provide the amount of feed stipulated for that animal, and also to certify if it is
} 
This information is updated daily so to follow the evolution of the udder during lactation. This capacity for "retroaction" is what, for Simondon (2012), characterizes technical objects in the process of concretization, which makes them differ from non-concretized objects such as automatons, for example. It is this "margin of indeterminacy" that connects them to the exterior, making them sensitive to the external world.

However, Simondon clearly demonstrates that this process of concretization should not be taken to be a decrease in human activity, or a progressive domination of machines. For him, the mythical vision of a robot saturated with its own intentions is as unsustainable as a view of machines as mere aggregates of meaningless matter, the main attribute of which is their "utility" (ibid: 11). This is an important point for us to understand the relations that are established between breeders, cows and robots, since, as Simondon suggests, it is not possible to conceive of the suppression of the human and his or her replacement by the robot. The very existence of the robot as a technical object implies its insertion into the relations that are required for its functioning. Even if it contributes to the emergence of these relations - through its characteristics and capacities (abilities) - it is still part of the medium in which man, in the words of Simondon, is a "maestro" who organizes this network and its relational medium (ibid: Part II).

The breeder is thus a maestro of a robotized milking (or breeding ${ }^{20}$ ) system, managing relations that are woven by the installation of a milking robot. This is true both of the use of data provided by the robot, and in relation to the adjustments and maintenance of its work (we will see shortly some of the daily practices associated with this). It is possibly in this characterization of the activity of breeders that we can understand and perceive the differences that they draw attention to when they speak of a "change in profession" or of "milking with a mouse".

Figure 8: "Roto" milking system (rotary parlour). The cows are on a plate that spins depending on the position in which they enter or exit, and in which humans stand in the external corridor.

The cows are milked from behind.

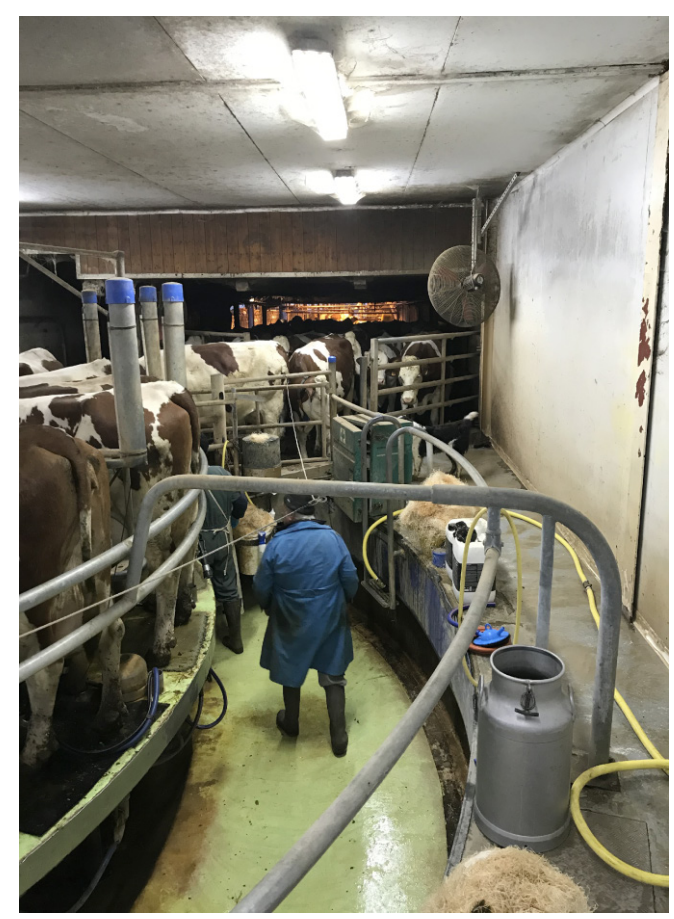

Photo by the Author.

apt to be milked - respecting the minimal interval between milking sessions.

20 The milking robot is not the only robotization possible in animal breeding: there are cleaning robots, and feeding robots, for instance. But, according to the breeders, the robotization of the breeding system, which acts upon the installations, causes less of an impact. 
We must be attentive to what is transformed and reorganized, as well as with what emerges, with the installation of a robot. Perhaps the most obvious and jolting transformation concerns rhythms. Since LeroiGourhan (1964) and Mauss (2012b), we have known of the importance of rhythm in the analysis of techniques. When we are dealing with manual, mechanized or robotized milking, we definitely see changes in rhythm. In milking, the activity of the hands is always interesting: in both manual and mechanized milking, hands move in gestures characteristic of milk extraction. In manual milking, gestures carried out with one hand stimulate the milk to flow through the teat, block possible backflow into the "quarter", and then exert pressure to make the milk shoot out of the teat. This movement is based on a rhythm that alternates between both hands, creating a corresponding swing in the gestures of the body. In mechanized milking, the gestures of the hand position sucking equipment on the cow's udder ${ }^{21}$. In this method of milking various cows can be milked simultaneously, but even so there is a rhythm to the gestures, which are repeated for each cow in an alternating sequence or in a continuous flow, depending on which system is adopted..$^{22}$

In the robotized system, the direct contact that occurs during milking is carried out by the robot, through a series of tactile sensors and lasers, and not by the breeder's hand. The movements of the hand in fact disappear. Milking continues to function through the alternating rhythm of the pneumatic system for sucking milk (with its characteristic sound). Sonic rhythms which not only regulate the activities of humans, but are also clearly perceived by the cows, as we will see. At this point we can already discern important changes in activity during milking which more or less correspond with the delegation of tasks.

IMG_1949This freedom ${ }^{23}$, however, does not feature much in the discourse of the breeders, for two reasons. The first is that freeing up time is not what allows breeders to "think" (in the sense intended by the salesmen). We know that "to do things with our hands" is already a way of thinking and that this hylomorphist way of dividing "doing" from "thinking" does not help us to understand what people do, nor why they do things in a specific way (c.f. Ingold 2000; Warnier 1999; Guchet 2016; Simondon 2005a). The second is that the idea of "freedom" depends on the presupposition that there is nothing else one needs to do with one's hand, which is distant from the reality of breeders.

Returning to the idea of 'rhythm', it is evident that implementation of a robot produces a drastic transformation in the collective human-cow rhythm. Both manual and mechanized milking must, in general, be carried out twice daily, with as equal an interval as possible (every 12 hours), typically at the start and the end of the daily routine.

\footnotetext{
21 Milk is then aspirated by a pneumatic system

22 In an alternating system cows are arranged in two rows. While one is milked, the other is being prepared. In more fluid systems, such as rotating systems, there is a continuous flow of cows entering the stall, and they are positions in a circular moving platform with an automatic system for removing the suction cups.

23 A term used by the salesman as a pitch: “... to free your hand to free you mind".
} 
Figure 9: Entering the "Roto" system. The corridor connects the waiting room to the milking plate. When they leave, they return through a corridor in the stable.

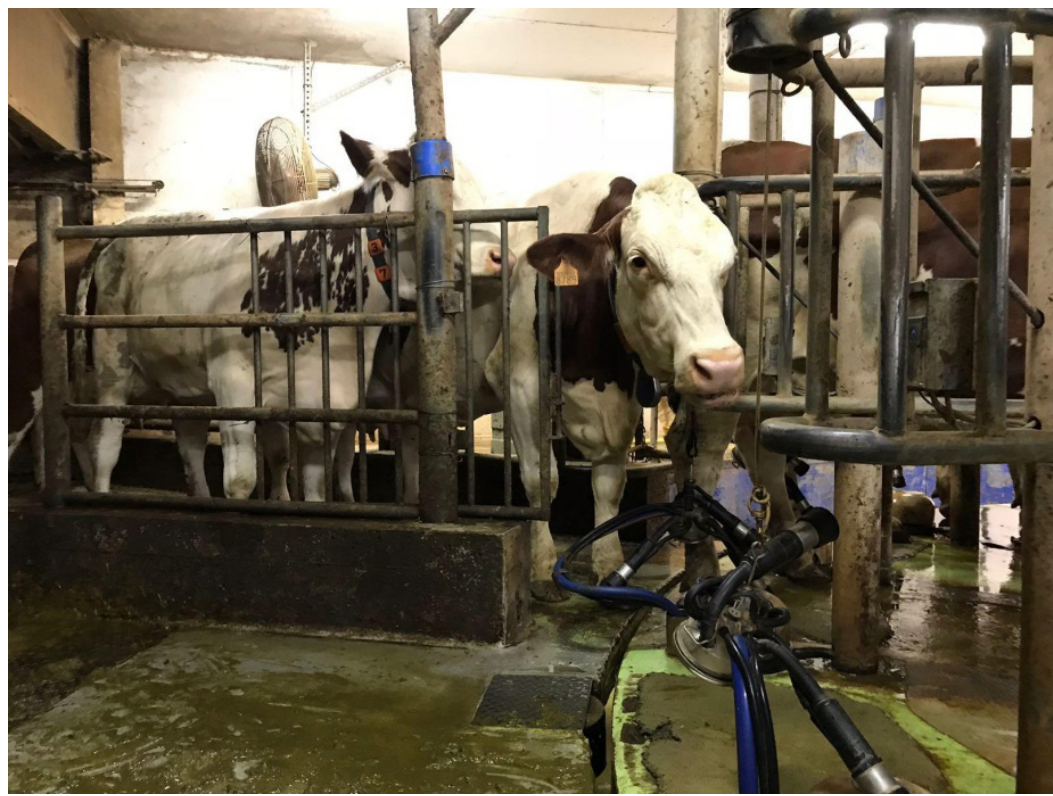

Photo samuelducloz@.

The robot requires a continual flow of milking animals that, in principle, choose when they want to be milked, since they enter the robot of their own accord. Yet the twice-daily rhythm continues to feature often in discourse and remains a paradigm of animal breeding. To breed milking cows is to milk them; to care for animals is to milk them as much as to feed them. These activities are closely related in manual as well as mechanized systems. Cleaning the stables, fixing or changing roofs of straw or other materials, are all activities that are set in accordance with the rhythm of milking. These activities are preferably carried out while cows are being milked, or when they are in the waiting room, which clears space for easy circulation. All of this synergy, this integration, is transformed by the robot. Since it sets a continuous flow, the daily rhythm of work vanishes, allowing for a greater independence of tasks. This rupture helps us understand what many breeders consider to be an important transformation of their profession (métier).

Furthermore, it seems to me that the loss of the herd effect, which many breeders have observed, describes this transformation from a conjugated rhythm to a growing individualization of the animals. With the absence of the twice-daily milking schedule, animals no longer gather to pass through the milking stall; they are no longer grouped or confined to certain spaces (the waiting room). In practice, cows can move freely through various spaces in a more individualized and whimsical manner. The net result is a continual flux of cows wandering through the stables, going to pasture when this option is available to them, and going, on their own initiative, to "pass through the robot". In such an environment, humans also organize their own labour in a more fluid fashion. Even if robots clean certain areas of the stable or provide animals with feed, it would be a mistake to conclude that humans no longer "care for" their animals, since they must regularly pass through their midst. In other words, the loss of the twice-daily encounters does not reflect a distance between humans and cows - or, rather, if such a distance exists, it cannot be understood to be a consequence of the adoption of the robot. Constant care is necessary in the stable, including cleaning areas that are inaccessible to robots, controlling cows which are late for their turn (as signalled by the robot), and supervising the functioning of the machines and the well-being of the animals. The time made available by the robot is reinvested in the 
relationship with cows. As a consequence, there are important changes in the spaces wherein humans and cows circulate, which, as its counterpart, allows more intensive inter-specific relations, with more time spent in a single locale.

Figure 10: Integrating the robots to the stable. In the foreground, there is a space to eventually block cows that are late, forcing them to go through the robot in order to exit.

The barrier is raised when it is not in use (which is most of the time).

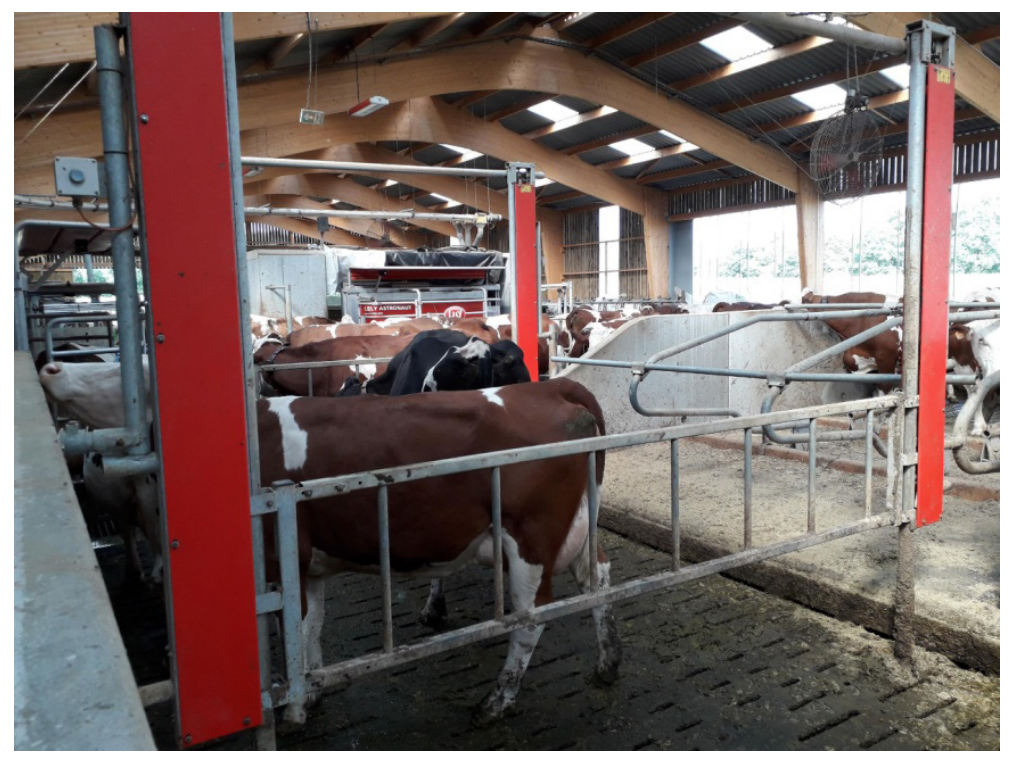

Image by the author.

This also impacts how breeders visually perceive their cows. In mechanical milking, the breeders' view of his cows is attuned mostly to their udders, with which he is frequently in contact. In the milking stall, humans are situated below the cows, with their field of vision limited by the udders. Breeders can, thus, recognize their cows by their udders. By spending more time with them in the stables, they also change their field of vision, apprehending their cows from above. ${ }^{24}$ The touching, caressing and shoving that takes place at these times are also different from touching during milking. It is impossible to caress a cow in the milking stall, where the animal's head is usually far from the field of vision of whoever is milking. With the robot, these encounters become more frequent, since the breeder spends more time between his cows.

Yet it would also be mistaken to assume that the robot estranges the breeder from the milking process. As the "maestro", he is always connected to the robot, through cell phone apps that inform him of events in real time: which cows have been milked, which are late and which, eventually, display a problem ${ }^{25}$. The computer also enables remote control: breeders can manipulate the robot from a distance, regulate the quantity of food supplements provided, and analyse the data. These activities take place all of the time (including holidays), anywhere at all, and with alarms sounding in the case of emergencies. In practice, breeders are constantly breeding their cows. What differs is the intensity and the rhythms deployed.

As we can see, the installation of a milking robot does not amount only to the robotization of a task, but also transforms the very breeding system and the relation of domestication, modifying rhythms and movements of humans and cows. This transformation does not take place in the change from manual to mechanized milking

\footnotetext{
24 The installation of a robot is frequently accompanied by the construction or rearranging of breeding installations, the stable, the place where calves are kept and to conserve milk, etc.

25 Breeders can be called on at any moment, having, for example, to interrupt what they are doing because a cow is blocking the robot.
} 
because both have similar rhythms, even if mechanization implies the adoption of specific installations. The same occurs in the change from a mechanized system of milking in which cows are lined up in rows - where the breeder positions himself in a pit between two rows of cows - to a rotary milking system, which requires the reconfiguration of the milking stall, but not of the rhythms involved ${ }^{26}$. The robot does not impose a strict rhythm, making the process more flexible and rendering a dedicated milking stall obsolete. Places for milking become integrated to the stable itself, strategically situated so as to facilitate the circulation and orientation of cows that pass through $\mathrm{it}^{27}$.

This has an influence on the behaviour of cows. Space is conceived to guide them and stimulate them towards making certain moves, the main one being their voluntary movement towards the milking robot. In a manual or mechanized system, times are imposed on cows by the breeders, with no room for negotiation with the animals beyond choosing whether they will be at the start of the end of the queue. This can generate conflict between humans and their animals and, according to breeders, they highlight personality traits of the cows. While some go through the process easily, other may need to be coerced, and some may refuse to go first or demand to go through only certain position $\mathrm{s}^{28}$. With the robot, they have a wider margin for action, with greater liberty to decide when they are milked $^{29}$.

In a very interesting article, Porcher and Schmitt (2010) ask whether, in this context, we can claim that cows participate in the work, and in what way this participation would occur. Without going into the issue of defining 'work' (the difference between collaborating with work and working (ibid: 256)), or of discerning what would be the practice of human work and the practice of animal work ${ }^{30}$, the authors clearly show the effects of a robot on cows through a study of the " conditions de travail d'un troupeau de vaches, leurs relations au travail - avec leur éleveur et entre elles - et leurs relations aux objets techniques" (:241). They point precisely to how cows adapt and react to conditions imposed by humans and robots; how they follow, anticipate or try to cheat the conditioning activities of both, getting up before their owners want to change they hay that they lie on, or else refusing to do so, for example, or exploiting a glitch in the robot's door to try and eat without being caught or avoiding being expelled right after having been milked (ibid: 253). What is fascinating is how they show that cows "understand" how the robot functions, and accordingly how they adjust, test or interpret the robot (particularly its sounds), and try to cheat the system. Thus, cows do not behave "mechanically" before the robot, just as they do not do so before the breeder (ibid: 254).

The behaviour and practices of both cows and breeders show us that the robot is not a mere device that automatically mimics humans, replacing their gestures and practices of milking. On the contrary, it is an example of how an apparent mechanical "complexification", a robotization, seems to delineate - in a certain context - not an "objectifying" distance in relation to the animals, as we might expect in processes of industrialization, but rather to consolidate the relations between humans, machines and animals. Techniques, or technical objects, take on the role of mediators in complex relational processes.

26 In a rotary milking system (rotary parlour), the flow of cows during milking is constant, following the spinning movement of the platform on which they are positioned. Thus, it differs from the system with rows because, when they enter the platform, cows sometimes have to be shoved.

27 A robot milks a herd of more or less 60 cows.

28 A classic case in systems with two rows in the milking stall is that of cows that only accept passing through the right side or the left.

29 Although some regulation is possible, the general minimum interval between milking is 6 hours. If a cow moves towards the robot before this time, it will be refused the food supplement and be expelled from the robot, with an "electric poke" if necessary. If a cow does not show up for more than 12 hours, the robot considers it to be late, signalling to the breeders that they may want to fetch it or to wait, if they deem that there is no rush (e.g., cows that are towards the end of the lactation period, for example, and which no longer produce much milk)

30 The authors point to what they see as a distinction between human work of maintenance and management, and animal work which occurs "concretely" in contact with the robot. If I understand correctly the distinction they propose, I do not agree with the dichotomous character they confer on it, mainly because the relation with the robot is apprehended as if it were an object separate from the "associated environment" (c.f. Simondon 2012). The authors do not take into account that the concrete and practical relation with the robot also occurs through, for example, cell phones. I do not think that the mastery to which Simondon refers concerning the role of humans in relation to technical objects assumes the form of a "maintenance". On the contrary, he shows that this is due to the separation between those who operate machines and those who operate the network in which they are inserted. It is thus a problem of the "Technical Culture of the West" (2012: Introduction) 


\section{Robots, humans and cows}

After the Green Revolution, the argument for "non-conformity" would supposedly distance us from processes of valuing creole races or of rediscovering neglected plants (Demeulenaere \& Goldringer 2017; Demeulenaere 2014). But, as we can see in studies of participative selection (Brac de la Perrière 2014; Bonneuil \& Demeulenaere 2007), or in agroforestry projects (Lafon 2016), for example, there is a constant attention to the connections between humans and plants or animals, through ways of acting and techniques of management. Environments made up of landscapes and mediums that appear to be more or less "technicalized" (in Simondon's (2005b) sense) nonetheless always form systems. That is, both the investment in creole races or varieties in the context of specific techniques or environments, and the installation of milking robots, can be apprehended through an analysis that enables us to conceive of agricultural processes as "triadic": techniques come to imply a mediation between humans, animals and the environment, in opposition to the binary logic of the "Green Revolution" (humans/nature). Robotization as a technical transformation of agricultural systems also raises a series of questions concerning the process of robotization, or on the "operation of mechanization" (Grimaud \& Vidal 2012). In a dossier they organized on the theme, Grimaud and Vidal (2012b) show that an anthropology of robotics requires that we understand robots and robotization through their modalities of action, their representations and multiple dimensions, in a panoptic and comparative perspective, since this is how robots are in the world and how they relate to humans.

Returning to milking robots, these appear, from this perspective, particularly intriguing, since they mechanize a specific gesture, or a series of gestures (an 'operational sequence'; c.f. Leroi-Gourhan 1964; Lemonnier 1992; Coupaye 2015), that are central to ways of "working with cows". With the introduction of robots, these gestures are becoming a mechanized operation, but, at the same time, we are not faced with an automised repetition.

Ce qui se machine n'est plus aujourd'hui forcément de l'ordre de l'automatisme et de la répétition ou des transferts de force et d'énergie. Désormais, il s'agit d'introduire de l'intelligence de calcul, du programme, voire de l'apprentissage. Les sequences de gestes automatisés ont fait place à des rapports plus qualitatifs de délégation, de complémentarité, de coaction et de coopération au sein d'agencements relationnels beaucoup plus compliqués et ambigus (Grimaud \& Vidal 2012a: 11).

As we have seen, the milking robot emerges as an instrument of multiple uses, depending on how it is represented, of the environments in which it will be used and the uses to which breeders will put it, affording new possibilities for breeding. It is a technical object, in Simondon's sense, and should be analysed as a technical process inserted in a network and its associated medium, composing thus a technical set. Along this line, we can also refer to the work of Dubois and Sauvée $(2016,2017)$, who consider modifications in the current agricultural landscape to be a new agricultural technique, in the manner of Simondon (following the studies of Guchet (2016)). Thus, the technical culture ${ }^{31}$ considered is one that is needed:

Pour redonner à la culture le caractère véritablement général qu'elle a perdu, il faut pouvoir réintroduire en elle la conscience de la nature des machines, de leurs relations mutuelles et de leurs relations avec l'homme, et les valeurs impliquées dans ces relations (Simondon 2012: 15).

Thus, humans and machines are to be reintegrated by the idea of the "set" and, above all, by perceiving machines as mediating technical objects, at once concrete and open; that is, inserted in multiple relations in an environment. We might see that humans, as much as robots and animals, are engaged in the constitution of a space, a common environment. What the milking robot seems to bring to this environment is its potential for

31 Technical culture is to be understood in Simondon's terms, relating to the adequacy of certain human practices and discourse and their degree of technicality: “conscience de la nature des machines." (Simondon 2012: 15). 
producing information and auto-regulation, but also its openness and concretude. With its own rhythms, its own spatial-temporal structuration, it is a mediator the activities of which are entwined with those of humans and animals. Indeed, the characteristic of this technical set, as Sigaut $(1976,2012)$ clearly points out, is that it is a three-way technical system: where living beings are diverse and disseminated, subject and object of different activities and in various contexts. Three terms: humans / robot (as technical object and associated environment) / cows - recalling the three terms that Stepanoff (2012) identifies in the reindeer breeding system in Siberia: human / environment / reindeer. The milking robot is the medium of the relation, a mediating technical object, and an associated environment, corresponding to Stepanoff's 'environment', which is entangled in the relation between humans and reindeer.

Figure 11: The breeder as maestro, fixing, verifying, always present... Part of the tasks are carried out continually for the system to work. Photo taken from the "human side" of the robot.

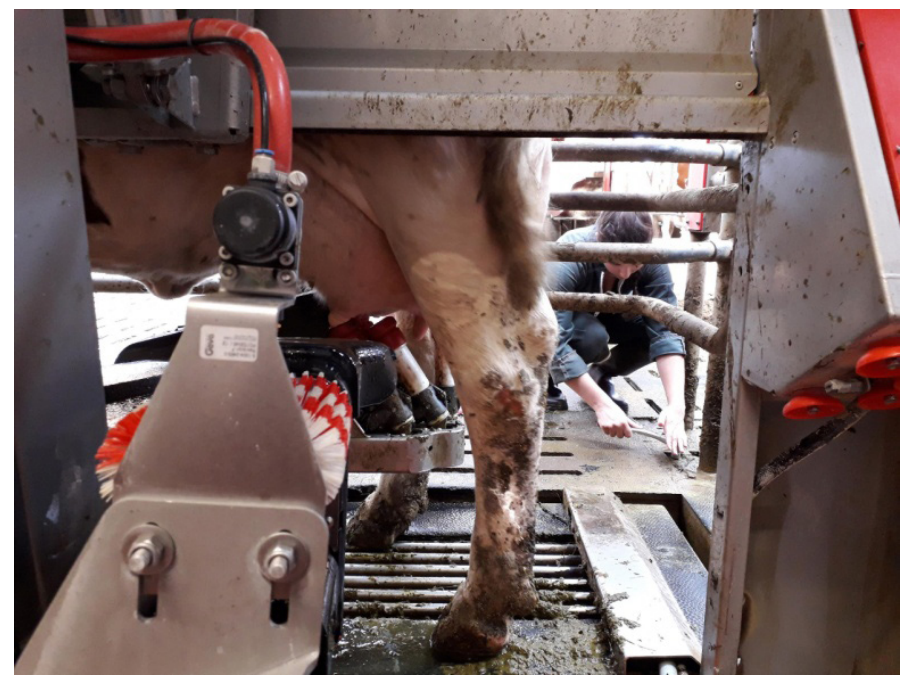

Image by the author.

The ideas of set and concretization are also fundamental in the matter of the representation of the machine, the industrial and objectification. As Dubois and Sauvee $(2016,2017)$ demonstrate, this issue can be understood as a backdrop to the current strands of agricultural diversification, including agroecology, permaculture, and organic agriculture. It may seem counter-intuitive to associate these agricultural techniques to the installation of a milking robot, but they too can be interpreted through this reinvention of an agricultural technical culture oriented towards concretude and synergy, where the "maestro" is the depository of skills, which Ingold had claimed were lost in the first investitures toward mechanization. Lost, not so much as a direct result of mechanization, but because of the loss of control and the possibilities of integrating them into an associated environment. 
It is worth considering what sort of rupture with traditional agricultural systems is instated by robotization. This leads us to other questions, and, more specifically, to a critique of the distinction between the categories of "artisanal" and "mechanic" proposed by Simondon, and to problems of scale. I cannot go into this issue here, but we can register the possibility of reflecting to what degree a new "technical culture" is, in fact, a rupture. In all cases we are left with the problem of interpreting contemporary robotization, which to Dubois and Sauvée seems like a characteristic of this new culture, but which presents a socio-political line of fracture between the milking robot and, say, permaculture. I think that this is due, precisely, to the following equation: mechanization/robotization $\Rightarrow$ industrial and Capitalist phenomena $\Rightarrow$ objectivization of nature.

On this issue, I disagree with Dubois and Suavé $(2016,2017)$, who adopt the equation from Guchet. If, on the one hand, it is positive and interesting to consider a technical culture that rethinks technique "comme relation constitutive des rapports Homme / Nature / Technique" (2017: 185), where the technical emerges as a medium (and system), on the other, and contrary to what they propose, it does not seem to be compatible with the maintenance of the idea of technique as an action upon nature à la Descartes. Following Simondon, the redefinition of agriculture and its relation to nature as an "imitation of nature", both in permaculture and in "ultra-technicalization", is incompatible with Descartes objectification of animal-machines (Guchet 2016: 138)32.

In this vein, the research of Porcher and Schmitt on how cows participate in work with the robot and the medium associated with it (with the human inside), shows that it is impossible to sustain a linear reading of the three-way relation, which is the principle of the Cartesian relation to living beings (Simondon 2004). It is interesting, as Porcher (2002: 199-210) sustains elsewhere, to perhaps think in terms of umwelt - centred on techniques in this context of domestication. A partially shared umwelt, common to humans / robots / cows.

However, this does not deny the relation between robotization, industrialization and Capitalism. In general, in order to install a milking robot, one needs to be inserted in industrial and Capitalist circuits. It is this relation to industry and Capitalism that allows agriculturalists to technically transform their systems, but also keeps them in a financially difficult situation where they retain a very low level of power in making decisions (Droz 2002; Droz \& al 2014). I also do not want to deny that, as an investment with consequences, the robot inexorably ties breeders in an asymmetrical relation to the Capitalist and industrial system that moves the world economy. However, I also consider that the installation of a milking robot in an agricultural system does not automatically imply a progression in the industrialization of the system of agriculture and breeding, nor does it necessarily represent an advancement towards a model which objectifies animals and transforms them into machines in relation to which humans become mere business managers. Unlike many agricultural engineers and zootechnicians, agriculturalists in general manage to remain agriculturalists and do not convert completely to a Cartesian industrialism (at least in what concerns their relations with animals) and to the Fordism of business management. If, in fact, the industrial system (such as in pig breeding) transforms animals into mere objects, it only does so through a crisis of representation of those who work in this industry (Porcher 2002; Mouret 2012: 107-132); that is, when they no longer see themselves as animal breeders, and are no longer so seen by others.

Hansen $(2013 ; 2014)$ describes a similar phenomenon in the transformations of dairy farming in Hokkaido, Japan. In the social and political context of a crisis of alimentary insecurity (Hansen 2014: 58), Japan pioneered a radical transformation in the system of dairy farming in Hokkaido. Promoting strong industrialization, within which heavy investment in "new technologies" resulted in what, to do the author, is a loss of skill

32 I am unable to discuss this in detail in this article, but, following Canguilhem's (2008) reading of Descartes, for instance, we are forced to conclude that the radical distinction between Human/Nature and Soul/Body in Descartes is incompatible with the Simondonian interpretation of the relation to nature and technique. 
(Hansen 2013: 54-55) by the workforce, mostly waged labourers, while landowners came to assume the position of business managers. This industrialization caused an increase in production and farm size (as well as an overall reduction in the number of farms), from dozens of cows per farm to hundreds and even thousands.

In his 2013 article, the author shows how this process occurred through the intensive use of a milking system called the 'rotary parlour', which allowed this industrialization to take place by the concomitant proletarization of cows and workers, blurring the boundaries between them: "In other words, it is likely clear that with 1000 'livestocks' passing by high turnover workers with $18 \mathrm{~s}$ [second] window of contact, worker, bovine and equipment blur, again there is individuation but not individuals" (ibid: 7). The author explains that milking robots were not adopted in this case for a number of reasons, related to aborted efforts (breeders initially claimed that robots had significant problems), but also high costs and the investment needed to milk herds of hundreds of cows: unskilled workers and foreigners are still cheap in Hokkaido. If the implementation of the robot in cases such as that of the small-sized breeders in France, which I have analysed here, is an important transformation of human-animal relations, requiring different practices and strategies of care without, as such, being less attentive to animals, it is also possible that, in the context of a process of intensive industrialization, it may not be that well-adapted.

However, Hansen interestingly shows how a technical object is inserted in a process of industrialization that objectifies humans and animals. Nonetheless, it does not seem to me that there is a necessary causal link between the former and the later. The "rotary parlour", or roto, as it is known where I carried out fieldwork, is the rotating system of milking (figures 8 and 9). In the cases that I investigated, it is not possible to conceive of them in the same way that Hansen does for the process of industrialization in Hokkaido. As I have claimed, in this system, as in other systems of mechanical milking, breeders recognize their cows via their udders, and they hence remain individualized. It does not annul the effects of continuous communication between humans and cows, nor does separate workers from managers. It does not seem to me that the rotary parlour is, in itself, an industrialization of the milking process that creates a distance between human (owners) and cows by their objectification and through waged labour. But it can, of course, be an instrument of industrialization when it is inserted into a socio-economic and political context like that of Hokkaido.

Figure 12: "Our cows are milked in a calm and silent environment. Thank you for not yelling".

Sign placed at the entrance of the human space of the robot.

The installation of the robot does, in fact, attract visitors.

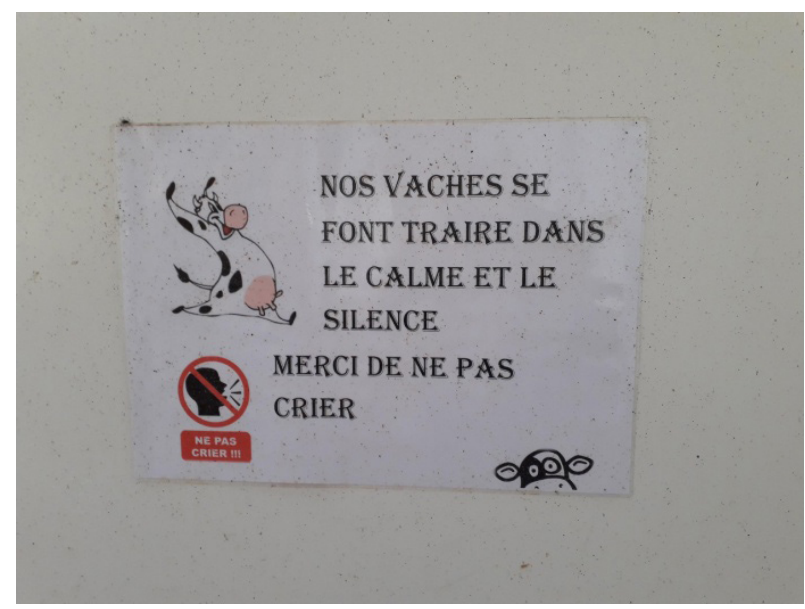

Image by the author. 
Likewise, this shift is not effected by the robot, but by its context of actual and potential use. Effectively, it constructs a new technical relation with animals and implies distinct associated means in what pertains to their rhythms and spaces for mechanical and manual milking. The robot also further integrates breeders to a Capitalist system, because of high costs and diverse economic and political chains that connect them. The installation of a robot transforms and renders necessary a new integration of techniques, humans and animals, and the result can be conducted in different ways according to the uses to which the breeder puts the robot. He can use it to maximize the production of milk, thus setting the distribution of food supplements with that aim in mind, but this implies a constant tension between managing the herd to avoid the negative effects of pousser les vaches. ${ }^{33}$ Thus, this option is possible, and can be a reaction to certain economic imperatives, but it is not a necessary condition emerging from the installation of a robot.

Similarly, the robot also enables a degree of pacification in the relation between animals and their breeders by affording greater room for manoeuvre to the animals and reconfiguring their movements and rhythms in a more fluid and idiosyncratic manner. Breeders are unanimous in saying that a good installation calms the herd, makes the cows more tranquil, less nervous and disturbed. There is certainly a regression in the change from a forced containment to a smoother coordination according to the cows' will. They still align, to a degree, with the interests of humans, who need to meet their cows at the same times and under the same conditions of tension (mechanized milking is, indeed, a tense moment, for various reasons, and this is reflected in relations maintained with animals $)^{34}$.

Figure 13: Strolling amidst the cow, cleaning manure on the sleeping mat, taking late cows to the robot, or spreading hay or sawdust on the carpet (task carried out in the mechanical system when the cows are not in the stable).

Tasks carried out at least twice daily.

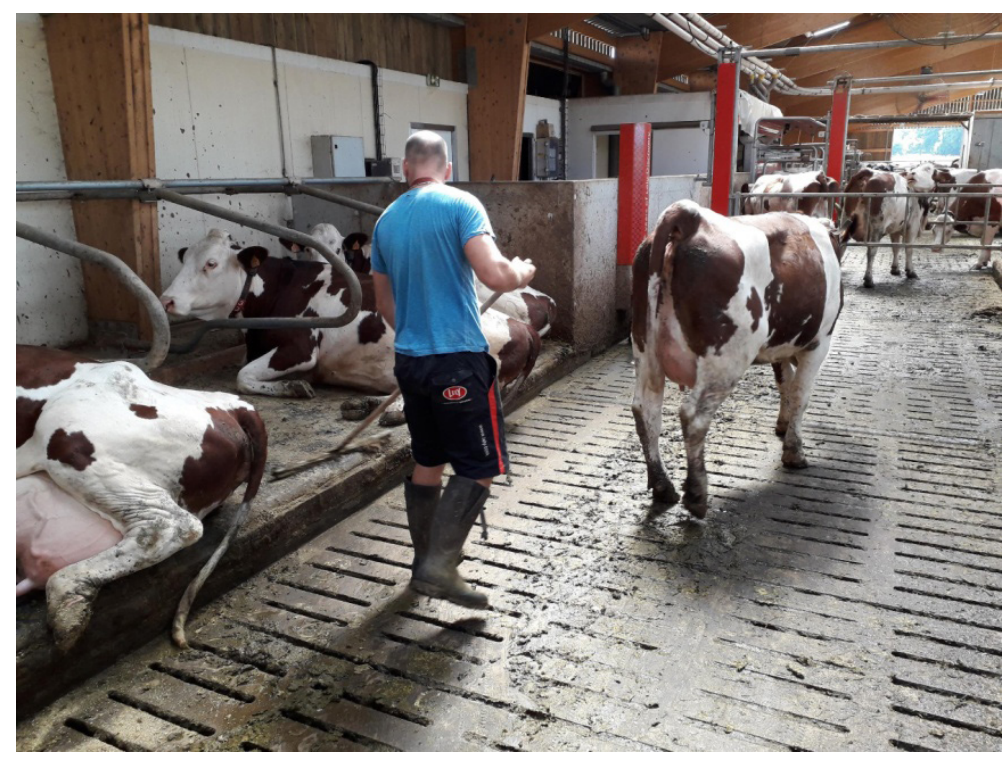

Photo by the Author

33 Pousser les vaches means 'to force the cows', by controlling nutrition and breeding conditions, seeking to maximize milk production. The tension between economic imperatives and affective relations is Always a sour point among breeders, because they have negative effects on the health and longevity of the animals.

34 It is difficult to be precise regarding the degree of containment involved in manual milking. However, it should be recalled that in many cases animals have to be docked to a space where milking will be carried out, and that often its legs have to be bound. 
In other words, reflecting on robotization in agricultural systems through a linear model that implies a growing distance between humans and animals, along with the objectification of the latter, does not capture the complexity and diversity of agricultural systems, nor the resilience of daily relations of coexistence and assemblage which are common to all relations of domestication. It seems evident to me that the installation of a robot transforms gestures, rhythms and skills, without thereby automatically delegating these aspects of human-animal relations, but, rather, creating a complex relational medium. As Holloway and Bear (2017) note, the constitution of the subjectivity of animals and humans is modified in relation to other milking systems, but without implying the loss of acting subjects. Following the analyses of Ferret $(2014,2016)$, we might say that the ways of doing implicit in any system of domestication are modified and transformed, but continue to be oriented by the characteristics of the living who are constituted at the edges of this technical relation.

Received: August 6, 2018

Accepted: May 9, 2019

Translation by Luiz Costa

\section{References}

BONNEUIL, Christophe \& DEMEULENAERE, Elise. 2007. Vers une génétique de pair à pair? L'émergence de la seléction participative. Version on-line Hal.Archives Ouvertes.

https://hal.archives-ouvertes.fr/hal-oo175991. Access: 22/03/2016.

BEDOUSSAC, Laurent et al. 2013. Pratiques agricoles innovantes et logistique des coopératives agricoles. Une éturde ex-ante sur l'acceptabilité de cultures associées blé dur-légumineuses. Economie Rural [en ligne], 338. Mise en ligne le 15 novembre 2015. http://economierural.revues.org/4145. Access: 02/01/2017.

BRAC DE LA PERRIÈRE, Robert, A. 2014. Semances paysannes, plantes de demain. Essai n. 207. Paris: Editions Charles Léopold Mayer.

CANGUILHEM, Georges. 2008. "Machine and organism”, Paola Marrati \& Todd Meyers (eds.), Knowledge of life. New York: Fordham University Press. Http://www.jstor.org/stable/j.cttıc5ck4q.9. Access: 29/12/2016. COUPAYE, Ludovic. 2009. "What's the Matter with Technology?" Australian Journal of Anthropology, 20(2): 91-111. . 2015. "Chaine opératoire, transects et théories : quelques réflexions et suggestions sur le parcous d'une méthode classique". In: Philippe Soulier (ed.), André Leroi-Gourhan "l'homme, tout simplement. Paris: Editions de Boccard. pp. 69-84

.; DOUNY, Laurence. 2010. "Dans la trajectoire des choses. Comparaison des approaches francophones et Anglophones contemporaines en anthropologie des techniques". Techniques \& Culture, 52-53: 12-39.

DARRÉ, Jean-Pierre. 2001. "Veaux bretons et brebis alpines, entre objectivisme abstrait et relativisme". Travail, 6: 89-103.

DEMEULENAERE, Élise; GOLDRINGER, Isabelle. 2017. "Semence et transition agroécologique: initiatives paysannes et sélection participative comme innovations de rupture”. Natures Sciencies Sociétés, $25: 555-559$. 
. 2014. "A Political Ontology of Seeds: the transformative Frictions of a farmers' movment in europeu".

Focaal - Jornal of Global and Historical Anthropology, 69: 45-61.

https://hal.archives-ouvertes.fr/hal-01016766. Acess: 13/03/2018.

DETURCHE, Jeremy. 2012. "As vacas da discórdia: gestão e raça do rebanho entre os criadores de vacas montbéliardes na Hautes-Savoie, França”. Ilha, Revista de Antropologia, 14: 139-170.

. 2017. "A genética do quotidiano: seleção e reprodução na criação de vacas montbéliardes (França)". In: Carlos Sautchuk (org.), Técnica e transformação: perspectivas antropológicas. Rio de Janeiro:

ABA Publicações.

DIGARD, Jean-Pierre. 1988. "Jalon pour une Anthropologie de la domestication animal". L'Homme, 28(108): 27-58.

. 1990. L'homme et les animaux domestiques. Anthropologie d'une passion. Paris: Fayard.

DROZ, Yvan. 2002. On achève bien les paysans. Suisse: Georg. et al. 2014. Malaise en Agriculture. Une approche interdisciplinaire des politiques agricoles France-QuebesSuisse. Paris: Karthala.

\& FORNEY, Jeremie. 2007. Un metier sans avenir? La grande transformations de l'agriculture suisse romande. Paris: Karthala.

DUBOIS, Michel J. F. \& SAUVÉE, Loïc. 2016. "Sens des évolutions agrotechniques contemporaines à la lumière des interactions systémiques”. In: (eds.), Évolution Agritechnique contemporaine; Les transformations de la culture technique agricole. Collection Ingénieur au XIXe siècle. Belfort: Université de Technologie de Belfort-Montbéliard. pp. 175-207

. 2017. "Transformations agrotechniques contemporaines: vers l'invention d'une nouvelle culture technique agricole?" Cahiers COSTECH, 1. http://www.costech.utc.fr/CahiersCOSTECH/spip.php?article58. Access: 18/07/2017.

FERRET, Carole. 2014. "Towards an anthropology of action: from pastoral techniques to modes of action". Journal of Material Culture, 19(3): 279-302.

. 2016. "Outils vivants? De la manipulation des animaux". In: Perig Pitrou; Ludovic Coupaye; Fabien Provost (orgs.), Des êtres vivants et des artefacts. L’imbrication des processus vitaux et des processos techniques IOfliving Beings and Artefacts. The Articulation os Vital and Technical processes, Paris, France. Actes du Colloque: Des êtres vivants et des artefacts. L'imbrication des processus vitaux et des processos techniques / Of living Beings and Artefacts. The Articulation os Vital and Technical processes (Musée du Quai Branly 9-10 avril 2014). https://hal.archives-ouvertes.fr/hal-01413482. Acess: 14/03/2018.

FIJN, Natasha. 2011. Living with Herds: Human-Animal Coexistence in Mongolia. Cambridge: Cambridge University Press.

FORNEY, Jeremie. 2012. Éleveur laitiers. Peuvent-ils surviure? Lausanne, Suisse: Presses Polytechniques et Universitaire Romande.

FRANZONI, Maiara. 2017. “Como a tecnologia está ajudando a evoluir o agronegócio brasileiro”. Lavoura, 10. http://blog.aegro.com.br/tecnologia-ajudando-agronegocio-brasileiro/ Access: 03/05/2018.

GRIMAUD, Emmanuel; VIDAL, Denis. 2012a. "Aux frontières de l'humain. Pour une anthropologie comparée des créatures artificielles". Gradhiva, Revue d'anthropologie et d'histoire des arts [en ligne], 15. Mis en ligne le 16 mai 2012. http://gradhiva.revues.org/2309. Access: 30/og/2016.

. (orgs.). 2012b Gradhiva Revue d'anthropologie et d'histoire des arts [en ligne], 15. Mis en ligne le 16 mai 2012 .http://journals.openedition.org/gradhiva/2302. Access: 30/og/2016. 
GUCHET, Xavier. 2016. “La nouvelle agriculture: une transformation de la conception de la nature?” In: Michel J. F. Dubois \& Loïc Sauvée (orgs.), Évolution Agritechnique contemporaine; Les transformations de la culture technique agricole. Collection Ingénieur au XIXe siècle. Belfort: Université de Technologie de Belfort-Montbéliard. pp. 129-144.

HANSEN, Paul. 2013. "Becoming bovine: Mechanics and metamorphosis in Hokkaido's animal-humanmachine". Journal of Rural Studies, XXX: 1-12. http://dx.doi.org/10.1016/j.rurstud.2013.02.001.

Access: 31/01/2019.

. 2014. "Culturing an agricultural crisis in Hokkaido". Asian Anthropology, 13(1): 52-71.

http://dx.doi.org/10.1080/1683478X.2014.889971. Access: 31/01/2019.

HAUDRICOURT, André-George \& DIBIE, Pascal. 1988. “Que savons nous des animaux domestiques?” L'Homme, 28(108): 72-83.

HOLLOWAY, Lewis; BEAR, Christopher. 2017. "Bovine and human becomings in histories of dairy

technologies: robotic milking systems and remarking animal and human subjectivity”. BJHS , 2 : 215-234. https://doi.org/10.1017/bjt.2017.2. The British Society for the History Of Science.

Cambridge University Press. Access: 03/02/2019.

INGOLD, Tim. 200oa. The perception of the environment: essays on livelihood, dwelling and skill. London and New York: Routledge.

. 20oob. "Tools, Mind and Machines: an excursion in the philosophy os technology". In: The perception of the environment: essays on livelihood, dwelling and skill. London and New York: Routledge. pp. 294-311. . 2010. "Retour "sur l'outil, l'esprit et la machine". Techniques \& Culture, 54-55(1): 288-290.

. 2011. "Walking the plank: meditations on a processo of skill". In: Being Alive: Essays on Movement, knowledge and description. London and new York: Routledge. pp. 51-62.

LAGNEAUX, Severine \& SERVAIS, Olivier. 2014. "De la traite robotisé au raid d'avatars. Incorporation et virtualization”. Parcours Anthropologiques, 9 [on-line]. URL : http://pa.revues.org/333. Access: 01/10/2016.

LAFON, Aubin. 2016. “L'agroforesterie, clé de voûte de l'agroécologie?” In: Michel J. F. Dubois \& Loïc

Sauvée (orgs.), Évolution Agritechnique contemporaine; Les transformations de la culture technique agricole: Collection Ingénieur au XIXe siècle. Belfort: Université de Technologie de Belfort-Montbéliard. pp. 109-126.

LEAL, Natacha. S. 2016. Nome aos bois. Zebus e zebueiros em uma pecuária brasileira de elite. São Paulo : Hucitec.

LEBRUN, Erick. 2016. “L'agriculture de précision et l'apport de l'utilisation de drones”. In: Michel J. F. Dubois \& Loïc Sauvée (orgs.), Évolution Agritechnique contemporaine; Les transformations de la culture technique agricole: Collection Ingénieur au XIXe siècle. Belfort: Université de Technologie de Belfort-Montbéliard. pp. 73-86.

LEMONNIER, Pierre. 1986. “The Study of Material Culture Today: Toward an Anthropology os Technical Systems". Journal of Anthropological Archeology, 5: 147-186.

. 1992. Element for an Anthropology of Technology. Anthropological Papers, 88. Ann Arbor:

University of Michigan. . 2010 [1983]. "L'étude des systèmes techniques, une urgence en technologie culturelle". Techniques \& Culture, 54-55(1): 46-67.

LEROI-GOURHAN, André. 1964. Le geste et la parole II. La mémoire et les rytmes. Paris: Albin Michel.

LIEN, Marianne Elisabeth. 2018. "Ducks into Houses; Domestication and Its Margins”. In: H. A. Swanson,

M. E. Lien \& G. B. Wenn (orgs.), Domestication Gone Wild; Politics and Practices of Multispecies relations.

Durham and London: Duke University Press. pp. 117-137.

LIZET, Bernadette. 1998. "Le génie des alpages. Paysage, vache, fromage en Abondance". Revue de Géographie Alpine, 86(4): 35-50. 
MAUSS, Marcel. 2012a [1935]. “Les techniques du corps”. In: Techniques, technologie et civilization présantation de Nathan Schlanger. Paris: Quadrige PUF. pp. 365-394

. 2012b [1906] "Essai sur les variations saisonnière des sociétés eskimos". In: Techniques, technologie et civilization présentation de Nathan Schlanger. Paris: Quadrige PUF. pp. 143-262

MAZOYER, Marcel \& ROUDART, Laurence. 2009 [1999]. Historia das agriculturas no mundo : do neolítico a crise contemporânea. São Paulo: Editora UNESP.

MICOUD, André. 2004. "Des patrimoines aux territoires durables. Ethnolgie et écologie dans les campagnes françaises". Ethnologie française, XXXVII(2):13 -22.

MOURET, Sébastien. 2012. Élever et tuer des animaux. Paris: Le Monde-PUF.

PORCHER, Jocelyne. 2002. Éleveurs et animaux, réinventer le lien. Paris: Le Monde - PUF. . \& SCHMITT, Tiphaine. 2010. "Les vaches collaborent-elles au travail? Une question de sociologie". La Découverte, I: 235-261. Revue du MAUSS. http://www.cairn.info/revue-du-mauss-2010-1-page-235.htm. Access: 01/02/2016.

RICARD, Daniel. 1998. "Produits de terroirs et normes de fabrication. Les fromages d'AOC face aux nouvelles exigences sanitaires". Revue de Géographie Alpine, 86(4): 103-114.

ROSCOE, Renato. 2013. “Tecnologia e Inovação na agropecuária brasileira”. Campo Grande News.

http://blog.aegro.com.br/tecnologia-ajudando-agronegocio-brasileiro/ Acess: 03/05/2018.

SAUTCHUK, Carlos. E. 2010. "Ciência e técnica". Horizontes das Ciências sociais no Brasil - Antropologia: 97-122. São Paulo: ANPOCS.

SIGAUT, François. 1976. "Une discipline scientifique à développer: la technologie de l'agriculture".

Cahiers des Ingénieurs Agronomes, 307: 16-21; 309: 15-19. . 1985. "More (and enough) on technology!" History and Technology, 2: 115-132. . 1988. “Critique de la notion de domestication". L'Homme, 28(108): 59-71. . 2012. Comment Homo devint faber. Paris: CNRS Éditions.

SIMONDON, Gilbert. 2004. Deux leçons sur l'animal et l'homme. Presentation by Jean-Yves Chateau. Paris: Ellipses. $92 \mathrm{p}$. . 2005a [2013]. L'individuation à la lumière des notions de forme et d'information. Grenoble: Millon. . 2005b. L'invention dans les techniques. Cours et conferences. Traces écrites. Paris: Seuil. . 2012 [1958]. Du mode d'existence des objets techniques. Paris: Aubier Philosophie.

STEPANOFF, Charles. 2015. "Comment les chasseurs de l'Artique sont-ils devenus pasteurs nômades? Le rôle du comportement animal dans la 'révolution du renne"'. In: N. Naudinot, L. Meignen, D. Binder \& G. Querré (eds.), Les systèmes de mobilité de la préhistoire au moyen âge. Antibes: Éditions APDCA. pp. 29-44. TSING, Anna. 2018. "Provocation: Nine Provocations for the study of Domestication”. In: A. S. Heather; M. E. Lien \& G. B. Wenn (orgs.), Domestication Gone Wild; Politics and Practices of Multispecies relations. Durham and London: Duke University Press. pp. 231-251.

WARNIER, Jean-Pierre, 1999. Construir la culture matérielle. L’homme qui pensait avec ses doigts. Paris: PUF.

Jeremy Deturche

Federal University of Santa Catarina, Brazil

https://orcid.org/oooo-0002-4956-8719

Author's e-mail: deturche@gmail.com 